\title{
Down-Regulation of $\beta_{1 \mathrm{C}}$ Integrin in Breast Carcinomas Correlates with High Proliferative Fraction, High Histological Grade, and Larger Size
}

\author{
Michela Manzotti, ${ }^{*}$ Patrizia Dell'Orto, ${ }^{*}$ \\ Patrick Maisonneuve, ${ }^{\dagger}$ Mara Fornaro, ${ }^{\ddagger}$ \\ Lucia R. Languino, ${ }^{\ddagger}$ and Giuseppe Viale* \\ From the Departments of Pathology and Laboratory Medicine* \\ and Epidemiology and Biostatistics, ${ }^{\dagger}$ European Institute of \\ Oncology, University of Milan School of Medicine, Milan, Italy; \\ and the Department of Pathology, Yale University School of \\ Medicine, New Haven, Connecticut
}

$\beta_{1 C}$ integrin is an unspliced form of the integrin $\beta_{1}$ subfamily, which has been shown to inhibit cell proliferation in vitro. Using an affinity-purified rabbit antibody, we have investigated 283 previously untreated breast carcinomas, with the aim of ascertaining the actual prevalence of $\beta_{1 \mathrm{C}}$ expression in these tumors and of defining its pathological correlates. Immunoblotting and reverse transcriptase-polymerase chain reaction experiments have also been performed in selected cases, to confirm the immunocytochemical findings. Overall, $\beta_{1 \mathrm{C}}$ immunoreactivity was down-regulated (ie, expressed in $<50 \%$ of the neoplastic cells) in 114 cases $(40.3 \%)$. Down-regulation of $\beta_{1 \mathrm{C}}$ expression in breast carcinomas correlated significantly with the tumor grade, the proliferative fraction (as evaluated by Ki-67 immunostaining with the MIB-1 monoclonal antibody), the estrogen and progesterone receptor status, and the tumor size ( $\mathrm{pT}$ classification) and marginally with the node status. In a multivariate analysis with all available measures fitted simultaneously, tumor grade $(P=0.004)$, Ki-67 immunolabeling $(P=0.01)$, and $\mathrm{pT}$ categories $(P=0.04)$ were significantly associated with $\beta_{1 C}$ immunoreactivity. Although the short follow-up time (2-3 years) of the current series of patients does not allow the performance of survival analyses, the correlation of $\beta_{1 C}$ expression with tumor size, grade, and proliferative fraction and its alleged role as an upstream regulator of $\mathrm{p}^{2} 7^{\mathrm{kip} 1}$ make this integrin variant a likely novel prognostic parameter for invasive carcinomas of the breast. (Am J Pathol 2000, 156:169-174)

The integrin family of cell adhesion receptors plays a pivotal role in the regulation of different cell functions, including proliferation, migration, intracellular signaling, and gene induction. ${ }^{1}$ The $\alpha$ and $\beta$ cytoplasmic domains modulate the effects of integrins, and the occurrence of several alternatively spliced variants of these domains possibly accounts for the variety of biological functions of these receptors.

Among the five known alternatively spliced forms of the integrin $\beta_{1}$ subfamily, $\beta_{1 \mathrm{C}}$ contains an unique unspliced intervening 116-bp sequence (exon C), which codes for a peculiar 48-amino-acid $\mathrm{COOH}$-terminal sequence. ${ }^{2}$ This integrin has been shown to inhibit cell proliferation in vitro, ${ }^{3-6}$ and its expression in epithelial cells of the prostate and bile ducts correlated with a nonproliferating, differentiated phenotype. It is interesting that $\beta_{1 \mathrm{C}}$ integrin is down-regulated in prostatic adenocarcinoma ${ }^{6,7}$ and in some non-small-cell lung carcinomas. ${ }^{8}$

Using an affinity-purified rabbit antibody, ${ }^{7}$ we have documented consistent immunoreactivity for $\beta_{1 \mathrm{C}}$ of the epithelial (luminal) cells of the normal mammary ducts and acini. Prompted by this observation, we have extended our investigation to a series of breast carcinomas to ascertain the actual prevalence of $\beta_{1 \mathrm{C}}$ expression in these tumors and define its pathological correlates.

\section{Materials and Methods}

\section{Tissue Specimens}

We analyzed 283 consecutive and previously untreated invasive cancers of the female breast, which were diagnosed and treated at the European Institute of Oncology (Milan, Italy). The tumors were histologically classified by the World Health Organization Histological Classification of Breast Tumors, ${ }^{9}$ as modified by Rosen and Oberman. ${ }^{10}$ There were 227 invasive duct carcinomas not otherwise specified, 25 invasive lobular carcinomas, and 31 other tumor types (medullary, tubular, cribriform, and mucinous).

Supported by grants from the Italian Ministry of Health, Rome, Italy, and the University of Milan, Milan, Italy (to G. V.), and by National Institutes of Health grant CA-71870 (to L. R. L.)

Accepted for publication September 27, 1999

Address reprint requests to Prof. Giuseppe Viale, Department of Pathology and Laboratory Medicine, European Institute of Oncology, Via Ripamonti 432, I-20141 Milan, Italy. E-mail: gviale@ieo.it. 
Table 1. Correlation between $\beta_{1 \mathrm{C}}$ Immunoreactivity and the Pathological Characteristics of the Tumors Under Study

\begin{tabular}{|c|c|c|c|c|c|}
\hline \multirow[b]{2}{*}{ Pathological characteristic } & \multicolumn{5}{|c|}{$\beta_{1 \mathrm{C}}$ Immunoreactivity } \\
\hline & Total & $<10 \%$ & $10-50 \%$ & $>50 \%$ & $P$ value \\
\hline All cases & 283 & $42(14.8 \%)$ & $72(25.4 \%)$ & $169(59.7 \%)$ & \\
\hline \multicolumn{6}{|l|}{ Tumor type } \\
\hline Invasive ductal NOS & 227 & $38(16.7 \%)$ & $58(25.6 \%)$ & $131(57.7 \%)$ & \\
\hline Invasive lobular & 25 & $2(8 \%)$ & $9(36 \%)$ & $14(56 \%)$ & \\
\hline Other types & 31 & $2(6.5 \%)$ & $5(16.1 \%)$ & $24(77.4 \%)$ & \\
\hline \multicolumn{6}{|l|}{ Tumor grade } \\
\hline $\mathrm{G}_{1}$ & 76 & $1(1.3 \%)$ & $6(7.9 \%)$ & $69(90.8 \%)$ & \\
\hline $\mathrm{G}_{2}$ & 96 & $15(15.6 \%)$ & $24(25 \%)$ & $57(59.4 \%)$ & \\
\hline $\mathrm{G}_{3}$ & 111 & $26(23.4 \%)$ & $42(37.8 \%)$ & $43(38.7 \%)$ & $P<0.001$ \\
\hline $\begin{array}{l}\text { pT classification } \\
\text { pT1 }(a, b, c)\end{array}$ & \multicolumn{3}{|c|}{ pT classification } & $119(66.1 \%)$ & \\
\hline pT2-4 & 100 & $20(20 \%)$ & $31(31 \%)$ & $49(49 \%)$ & $P=0.015$ \\
\hline Unknown & 3 & 2 & 0 & 1 & \\
\hline \multicolumn{6}{|l|}{ Node status } \\
\hline Negative & 118 & $18(15.3 \%)$ & $21(17.8 \%)$ & $79(66.9 \%)$ & \\
\hline Positive & 155 & $23(14.8 \%)$ & $46(29.7 \%)$ & $86(55.5 \%)$ & $P=0.069$ \\
\hline Unknown & 3 & 2 & 0 & 1 & \\
\hline \multicolumn{6}{|l|}{ Ki-67 immunostaining } \\
\hline $1-9 \%$ & 59 & $2(3.4 \%)$ & $6(10.2 \%)$ & $51(86.4 \%)$ & \\
\hline $10-19 \%$ & 80 & $8(10 \%)$ & $24(30 \%)$ & $48(60 \%)$ & \\
\hline $20-29 \%$ & 59 & 10 (16.9\%) & $8(13.6 \%)$ & $41(69.5 \%)$ & \\
\hline $30-39 \%$ & 36 & $7(19.4 \%)$ & $10(27.8 \%)$ & $19(52.8 \%)$ & \\
\hline $40-49 \%$ & 17 & $2(11.8 \%)$ & $11(64.7 \%)$ & $4(23.6 \%)$ & \\
\hline $50 \%$ and more & 32 & $13(40.6 \%)$ & $13(40.6 \%)$ & $6(18.8 \%)$ & $P<0.001$ \\
\hline \multicolumn{6}{|l|}{ ER status } \\
\hline Negative & 83 & $24(28.9 \%)$ & $26(31.3 \%)$ & 33 (39.8\%) & \\
\hline Positive & 200 & $18(9 \%)$ & $46(23 \%)$ & $136(68 \%)$ & $P<0.001$ \\
\hline \multicolumn{6}{|l|}{ PgR status } \\
\hline Negative & 151 & $32(21.2 \%)$ & $42(27.8 \%)$ & $77(51 \%)$ & \\
\hline Positive & 132 & $10(7.6 \%)$ & $30(22.7 \%)$ & $92(69.7 \%)$ & $P<0.001$ \\
\hline
\end{tabular}

Abbreviations: NOS, not otherwise specified; PT, tumor stage; ER, estrogen receptor; PgR, progesterone receptor.

Hematoxylin and eosin (H\&E)-stained sections were reviewed to evaluate tumor type and grade. Grading of tumors was by the method of Elston and Ellis. ${ }^{11}$ Sections of all cases already immunostained as previously report$\mathrm{ed}^{12}$ for estrogen (ER) and progesterone receptors (PgR) and for the Ki-67 antigen (using the MIB-1 monoclonal antibody) were also reevaluated. The pathological classification of the tumors was retrieved from the original pathological reports and recorded (Table 1).

\section{Immunohistochemistry}

Consecutive serial sections were cut from the same formalin-fixed, paraffin-embedded tissue blocks used for the immunohistochemical evaluation of the hormone receptor status and of the proliferative fraction and were immunostained for $\beta_{1 \mathrm{C}}$ with an affinity-purified polyclonal antibody. ${ }^{7}$

Described briefly, the procedure was next to dewax and rehydrate the sections. Endogenous peroxidase was quenched with $3 \% \mathrm{H}_{2} \mathrm{O}_{2}$ in distilled water for 5 minutes at room temperature. The sections were then sequentially incubated with the primary antibody $(1.7 \mu \mathrm{g} / \mathrm{ml})$ and the Dako EnVision detection system (Dako, Glostrup, Denmark), by the manufacturer's instructions.

Negative control sections were immunostained with the affinity-purified antibody to $\beta_{1 \mathrm{C}}$ preabsorbed for 30 minutes at $4^{\circ} \mathrm{C}$ with $10 \mu \mathrm{g} / \mathrm{ml} \beta_{1 \mathrm{C}} 785-808$ peptide, and the specific immunoreactivity was abolished. Double im- munostaining experiments for the simultaneous localization of $\beta_{1 \mathrm{C}}$ and $\mathrm{Ki}-67$ antigen were performed in selected cases, as previously described. ${ }^{13}$

The immunostaining results were independently evaluated by three investigators and scored in three classes by the percentage $(<10 \% ; 10-50 \% ;>50 \%)$ of cells showing definite immunoreactivity over the total number of neoplastic cells in 10 randomly selected high-power $(\times 400)$ fields.

\section{Messenger RNA Amplification by Reverse Transcriptase-Polymerase Chain Reaction}

Total cellular RNA was isolated from frozen tissue samples of six breast carcinomas (two exhibiting intense and diffuse immunoreactivity for $\beta_{1 \mathrm{C}}$ and four devoid of $\beta_{10}$ immunoreactivity), using TRIzol reagent (Life Technologies, Inc., Gaithersburg, MD) by the manufacturer's instructions. RNA $(1 \mu \mathrm{g})$ was reverse transcribed for 1 hour at $37^{\circ} \mathrm{C}$ in $20 \mu$ l of $1 \times$ first-strand buffer (Life Technologies), $10 \mathrm{mmol} / \mathrm{L}$ dithiothreitol (Life Technologies), 1 mmol/L dNTPs (Pharmacia, Uppsala, Sweden), 2.5 $\mathrm{mmol} / \mathrm{L} \mathrm{MgCl}_{2}$ (Perkin Elmer, Foster City, CA), $2.5 \mu \mathrm{mol} / \mathrm{L}$ Random Hexamers (Perkin Elmer), $20 \cup$ RNase inhibitor (Perkin Elmer), and $200 \mathrm{U}$ mouse murine leukemia virusreverse transcriptase (Life Technologies).

To check for the integrity of amplifiable complementary DNA templates, the samples were first amplified for $\beta$-ac- 


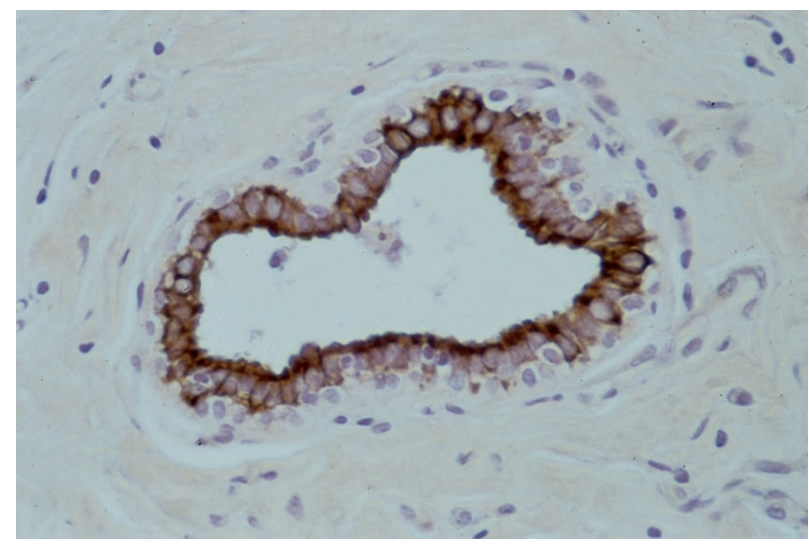

Figure 1. Intense $\beta_{1 \mathrm{C}}$ immunoreactivity in the luminal epithelial cells of a normal mammary duct. Original magnification, $\times 400$.

tin complementary DNA, using the specific primers BACT2284F and BACT-3000R (5'-GAAATCGTGCGTGACATTAGG-3', and 5'-CTAGAAGCATTTGCGGTGGA-3').

Two consecutive rounds of polymerase chain reaction (PCR) with $\beta_{1 C^{-}}$specific primers (forward, 5'-TCTGTCGCCCAGCCTGGAGTG-3'; reverse, 5'-TTTCCCTCATACTTCGGATTG-3') were then carried on to amplify a 172-bp sequence of $\beta_{1 C}$ complementary DNA. Described briefly, $4 \mu \mathrm{l}$ of complementary DNA were subjected to a first round of amplification in $50 \mu$ l of $1 \times$ PCR Buffer II (Perkin Elmer), $100 \mu \mathrm{mol} / \mathrm{L}$ dNTPs (Pharmacia), $2 \mathrm{mmol} / \mathrm{L} \mathrm{MgCl}_{2}$ (Perkin Elmer), $0.025 \mathrm{U} / \mu \mathrm{l}$ AmpliTaq Polymerase (Perkin Elmer), $0.1 \mu \mathrm{mol} / \mathrm{L}$ forward primer, and $0.4 \mu \mathrm{mol} / \mathrm{L}$ reverse primer. Twenty cycles of 30 seconds at $94^{\circ} \mathrm{C}$ and 1 minute at $68^{\circ} \mathrm{C}$ were run. Of the first amplification product, $4 \mu \mathrm{l}$ were then subjected to a second amplification round performed at the same conditions except for the annealing/extension step (touchdown). During the first nine cycles, the annealing/extension temperature was lowered from $67^{\circ} \mathrm{C}$ to $58^{\circ} \mathrm{C}$ and the time from 90 to 45 seconds (decreasing the annealing temperature $1^{\circ} \mathrm{C}$ and the time 5 seconds for each cycle). Eleven cycles of 30 seconds at $94^{\circ} \mathrm{C}, 45$ seconds at $58^{\circ} \mathrm{C}$, and 1 minute at $72^{\circ} \mathrm{C}$ were finally run.

$\beta_{1 \mathrm{~A}}$ messenger RNA (mRNA) amplification was performed in the same reaction buffer as for $\beta_{1 \mathrm{C}}$, using 0.1 $\mu \mathrm{mol} / \mathrm{L}$ of specific primers (5'-AGAATCCAGAGTGTCCCACTGG-3' and 5'-TTTCCCTCATACTTCGGATTG-3') and 30 cycles of 30 seconds at $94^{\circ} \mathrm{C}, 1$ minute at $55^{\circ} \mathrm{C}$, and 1.5 minutes at $72^{\circ} \mathrm{C}$. All of the PCR reactions were performed with a Perkin Elmer GeneAmp PCR System 2400. The PCR products were analyzed on a $2 \%$ agarose gel, stained with ethidium bromide.

\section{Immunoblotting}

Frozen tissue samples of five of the six breast cancers subjected to reverse transcriptase-PCR (RT-PCR) analysis (the two immunohistochemically positive samples and three of the four tumors nonimmunoreactive for $\beta_{1 \mathrm{C}}$ ), cryopreserved at $-80^{\circ} \mathrm{C}$ in OCT, were homogenized as previously described. ${ }^{5}$ The protein concentration, for each lysate was quantitated using the DC protein assay kit (BIORAD, Hercules, CA), according to the manufacturer's instructions.

To detect $\beta_{1 \mathrm{C}}$ and $\beta_{1 \mathrm{~A}}$ integrins, $200 \mu \mathrm{g}$ of lysate were electrophoresed on a $7.5 \%$ sodium dodecyl sulfate-polyacrylamide gel under reducing conditions and transferred to nitrocellulose (Schleicher \& Schuell, Keene, $\mathrm{NH}$ ) for 5 hours at $300 \mathrm{~mA}$ in $25 \mathrm{mmol} / \mathrm{L}$ Tris $(\mathrm{pH} \mathrm{8.3;} \mathrm{BDH,}$ Dorset, U.K.), $192 \mathrm{mmol} / \mathrm{L}$ glycine (Sigma), and 20\% methanol. Immunostaining was performed as previously described, ${ }^{7}$ with $7.5 \mu \mathrm{g} / \mathrm{ml}$ affinity-purified antibody to $\beta_{1 \mathrm{c}}, 7.5 \mu \mathrm{g} / \mathrm{ml}$ nonimmune rabbit immunoglobulin $\mathrm{G}$, or 5 $\mu \mathrm{g} / \mathrm{ml}$ monoclonal antibody to $\beta_{1 \mathrm{~A}}$ integrin (mAb 13; Becton Dickinson, San Jose, CA). Briefly described, after an incubation in blocking buffer $(20 \mathrm{mmol} / \mathrm{L}$ Tris, $\mathrm{pH} 7.5,150$ $\mathrm{mmol} / \mathrm{L} \mathrm{NaCl}$ ) containing $0.2 \%$ Nonidet P-40 (Calbiochem, San Diego, CA) and 5\% nonfat dry milk, the membrane was incubated with the primary antibody ( 1 hour at room temperature for $\beta_{1 \mathrm{~A}}$ and overnight at $4^{\circ} \mathrm{C}$ for $\beta_{1 \mathrm{C}}$ ). The filter was then washed three times in phosphatebuffered saline containing $0.2 \%$ Nonidet P-40 and incubated with the secondary peroxidase-conjugated antibodies for 1 hour, at room temperature. After three washes in phosphate-buffered saline-0.2\% Nonidet $\mathrm{P}-40$, proteins were visualized using the Amersham-ECL system (Amersham, Arlington Heights, IL), according to the manufacturer's instructions.

\section{Statistical Analysis}

$\beta_{1 \mathrm{C}}$ immunoreactivity was categorized into three categories $(<10 \%, 10-50 \%$, and $>50 \%$ neoplastic cells exhibiting immunostaining of the same intensity as the normal cell counterpart), Ki-67 immunoreactivity was divided into six categories (<10\%, 10-19\%, 20-29\%, 30-39\%, $40-49 \%$, and $>50 \%$ immunolabeled neoplastic cells), and ER and PgR immunoreactivities were dichotomized into two categories, using the staining of less than $20 \%$ or of $20 \%$ or more neoplastic cells as the cut-off value.

The association between $\beta_{1 \mathrm{c}}$ immunoreactivity and other clinico-pathological characteristics of the tumors was analyzed by the Fisher's exact test, and the strength of the linear relationship between variables was measured by Pearson's correlation coefficients. Logistic regression, with $\beta_{1 \mathrm{c}}$ immunoreactivity dichotomized as either $<50 \%$ or $\geq 50 \%$ immunostained cells as the dependent variable, was used to assess the independent association with all other available measures. All $P$ values were based on two-sided testing.

\section{Results}

Non-neoplastic breast tissue was present in 215 of the 283 samples investigated. The vast majority (75-100\%) of the epithelial (luminal) cells of the mammary ducts and 40 to $60 \%$ of the acinar cells were consistently decorated by the anti- $\beta_{1 \mathrm{c}}$ antibody. The immunoreactivity was particularly intense at the apical and basolateral cell membranes and weaker in the cytoplasm (Figure 1). $\beta_{1 \mathrm{C}} \mathrm{im}$ munoreactivity was cell type specific because it was restricted to the epithelial (luminal) cells, whereas myo- 

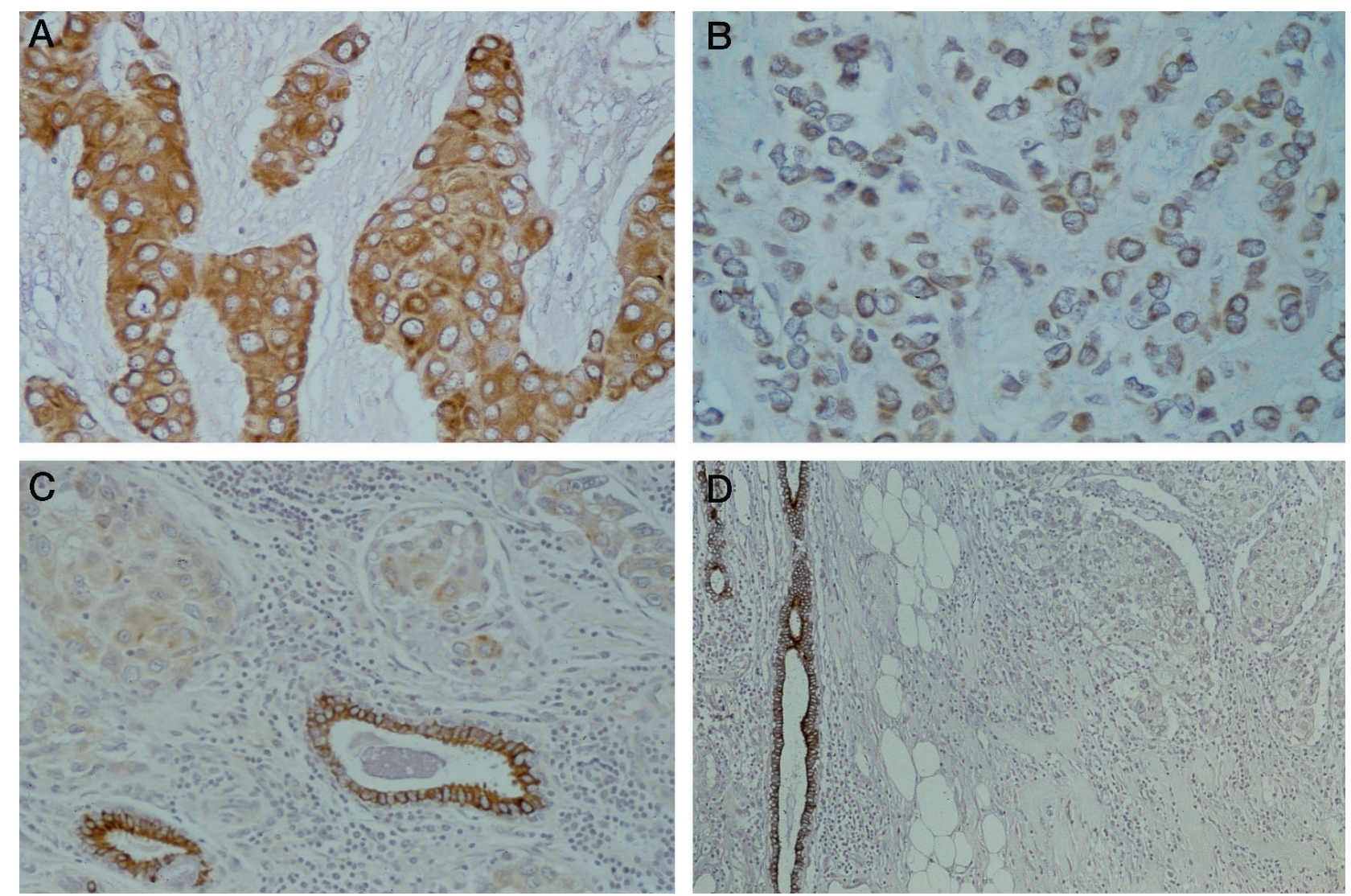

Figure 2. $\beta_{1 C}$ immunoreactivity is retained in the majority of invasive duct carcinomas $(\mathbf{A})$ and lobular carcinomas $(\mathbf{B})$ of the breast. Down-regulation $(\mathbf{C})$ or complete lack (D) of $\beta_{1 \mathrm{C}}$ expression is a feature of $40.3 \%$ of invasive carcinomas. Non-neoplastic mammary ducts provide built-in positive controls of immunostaining. Original magnifications: $\mathbf{A}$ and $\mathbf{B}, \times 400 ; \mathbf{C}, \times 250 ; \mathbf{D}, \times 100$.

epithelial, stromal, and inflammatory cells did not display any immunostaining, with the single exception of small and large nerves.

Overall, intense $\beta_{1 \mathrm{C}}$ immunoreactivity was maintained in more than $50 \%$ of neoplastic cells in $169(59.7 \%)$ tumors (Figure 2, A and B), and variably down-regulated

A

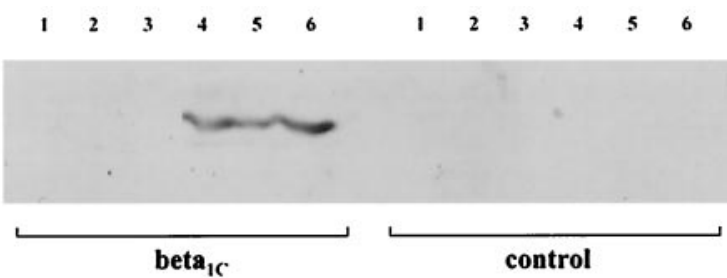

B

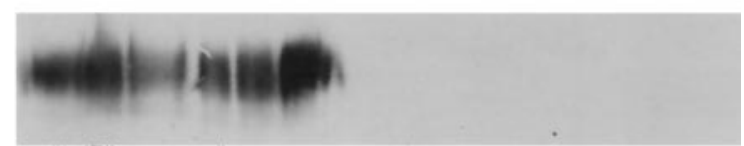

beta $_{1 \wedge}$

control

Figure 3. Immunoblotting analysis of five breast carcinomas immunostained for $\beta_{1 \mathrm{C}}(\mathbf{A}, 130-140 \mathrm{kd})$ and $\beta_{1 \mathrm{~A}}(\mathbf{B})$, as described in the text. B: Normal expression of $\beta_{1 \mathrm{~A}}$ in all of the samples. Lanes 1-3: The three cases that were not immunoreactive for $\beta_{1 \mathrm{C}}$ did not show any immunohistochemical staining as well. Lanes 4 and 5: The two immunoreactive cases were also intensely decorated by the antibody in tissue sections. Lane 6: Positive control (normal prostate). in the remaining 114 (40.3\%) cases (Figure 2, C and D; Table 1). The membranous and cytoplasmic localization of the immunoreactivity was comparable with that of the

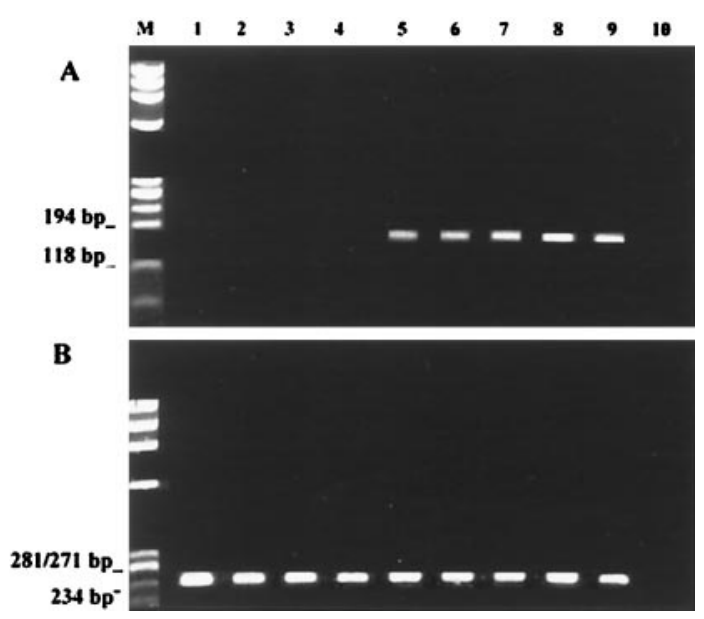

Figure 4. Ethidium bromide-stained gels of the RT-PCR experiments for amplification of $\beta_{1 \mathrm{C}}(\mathbf{A})$ and $\beta_{1 \mathrm{~A}}(\mathbf{B})$ mRNA of six breast carcinomas. Lack of amplifiable $\beta_{1 \mathrm{C}}$ mRNA in four breast carcinomas (lanes 1-4) correlated with the negative immunohistochemical and immunoblotting results. The two tumors showing amplified $\beta_{1 \mathrm{C}}$ mRNA (lanes 5 and 6) were also immunoreactive in immunocytochemistry and immunoblotting experiments. Lane 7: Normal breast tissue. Lane 8: Normal cell line (MCF10). Lane 9: Positive control (normal prostate). Lane 10: Negative control (no complementary DNA). 


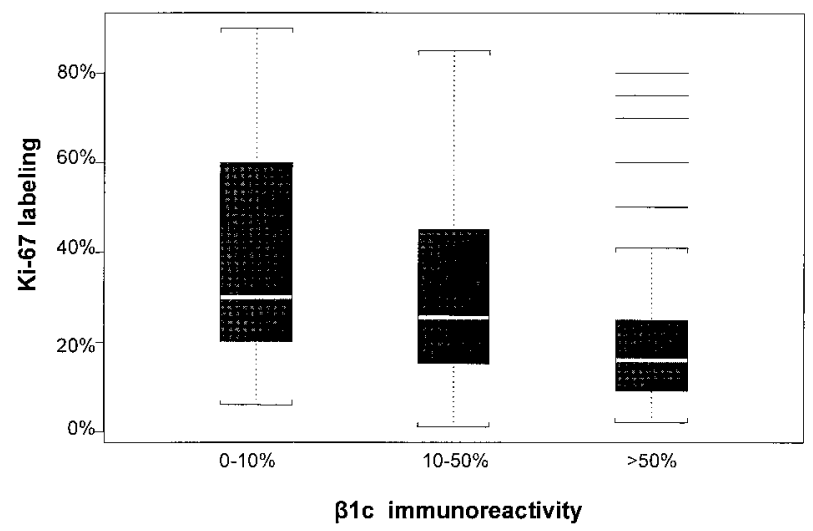

Figure 5. Box plots for the association between $\mathrm{Ki}-67$ and $\beta_{1 \mathrm{C}}$ immunoreactivities. The boxes represent the interquartile range (data from the 25 th to the 75 th percentile); the horizontal lines in the middle of the boxes represent the median or 50 th percentile of the data. The dotted lines emerging from the boxes extend to 1.5 -fold the interquartile range (whiskers). The horizontal lines at the top of the box for $\beta_{1 \mathrm{C}}$ immunoreactivity higher than $50 \%$ represent outliers (data points falling outside the whiskers).

normal cell counterpart in all cases in which non-neoplastic breast tissue was included in the tissue section.

The specificity of the immunohistochemical findings was confirmed by the immunoblotting experiments (Figure 3 ) and by the $\beta_{1 \mathrm{c}}$ mRNA amplification by RT-PCR (Figure 4).

$\beta_{1 \mathrm{c}}$ immunoreactivity in the whole series of tumors correlated significantly with the tumor grade, the proliferative fraction (as evaluated by Ki-67 immunostaining with the MIB-1 monoclonal antibody), the ER and PgR status (all $P<0.001$ ), the tumor stage (pT; $P=0.015)$, and marginally with the node status $(P=0.069$; Table 1; Figure 5).

In a multivariate analysis with all available measures fitted simultaneously, tumor grade $(P=0.004)$, Ki-67 immunolabeling $(P=0.01)$, and pT categories $(P=0.04)$ were significantly associated with $\beta_{1 \mathrm{C}}$ immunoreactivity.

Double immunocytochemical experiments documented a mutually exclusive expression of $\beta_{1 \mathrm{C}}$ and Ki-67 antigen by the vast majority of the neoplastic cells, with Ki-67-labeled cells being most often devoid of $\beta_{1 \mathrm{C}}$ immunoreactivity (Figure 6, A and B).

\section{Discussion}

We have documented for the first time the expression of $\beta_{1 \mathrm{C}}$ integrin in normal epithelial cells of the human female breast and its down-regulation in breast carcinomas. Breast epithelium should therefore be added to the list of human tissues expressing this unspliced variant of the $\beta_{1}$ integrin, which includes the luminal cells of the prostate, the epithelial cells of the bile ducts and gallbladder, the tubular cells of the kidney, and the bronchial epithelium. $^{5,8}$ In prostatic and bronchial epithelia, $\beta_{1 \mathrm{C}}$ immunoreactivity is restricted to the luminal (superficial) cells, with the basal (reserve) cells being consistently unreactive. In mammary ducts and acini, $\beta_{1 \mathrm{c}}$ expression is also strictly confined to the luminal epithelial cells and is not detectable in myoepithelial cells.

Down-regulation of $\beta_{1 \mathrm{C}}$ has been reported in 54 to $79 \%$ of prostatic carcinomas ${ }^{6,7}$ and in some pulmonary carcinomas. ${ }^{8}$ We now document that approximately $40 \%$ of female breast carcinomas are characterized by a downregulated expression of $\beta_{1 \mathrm{C}}$, with more than $50 \%$ of neoplastic cells failing to exhibit $\beta_{1 \mathrm{c}}$ immunoreactivity. Immunoblotting experiments and mRNA amplification by RT-PCR have confirmed the reliability of the above immunohistochemical findings.

Down-regulation of $\beta_{1 \mathrm{C}}$ is significantly correlated with prognostically relevant tumor parameters in invasive breast carcinomas. In univariate analyses, tumor grade, proliferative fraction, hormone receptor status, and pT classification were all significantly correlated with $\beta_{1 \mathrm{C}}$ expression, whereas axillary node status was not. In multivariate analysis, however, only tumor grade, PT classification, and the proliferative fraction retained a significant association with $\beta_{1 \mathrm{c}}$ expression, whereas the receptor status did not.

The strong inverse correlation of $\beta_{1 \mathrm{c}}$ expression with tumor grade in breast carcinomas is at variance with the lack of such correlation in prostatic carcinomas. ${ }^{6,7}$ This might well reflect that the grading systems for breast and prostatic carcinomas are construed on different morphological parameters. Indeed, Gleason's criteria ${ }^{14}$ for grading prostatic cancer rely on the gland-forming capability
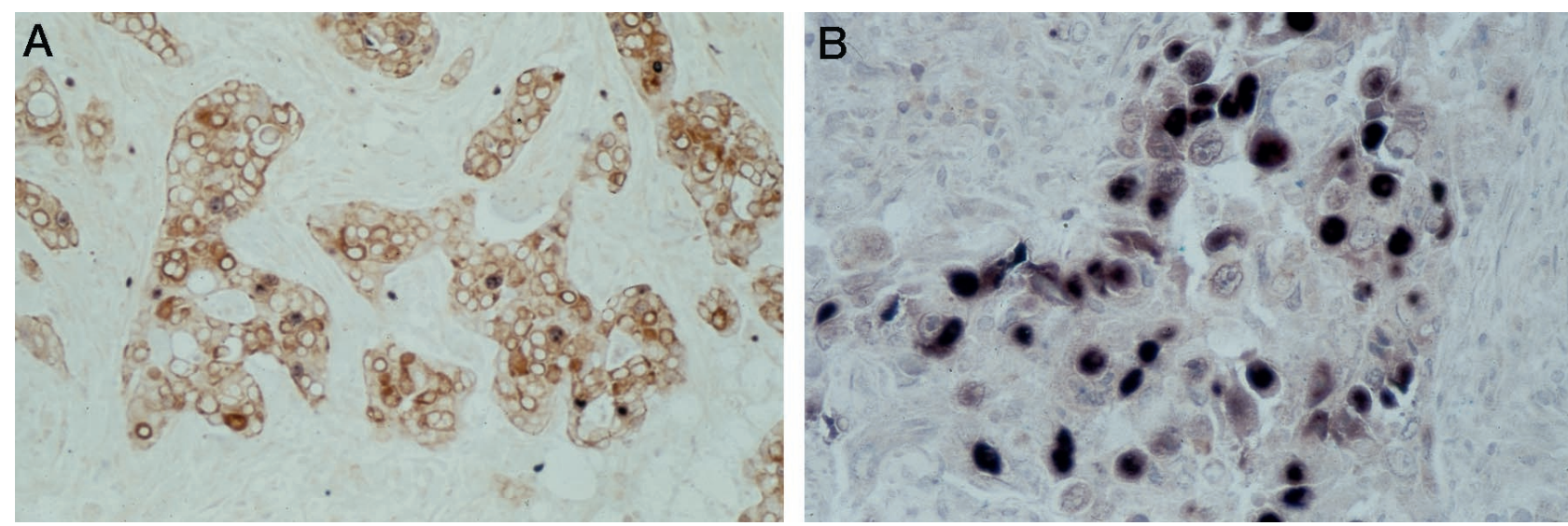

Figure 6. Double immunostaining experiments for the simultaneous localization of the Ki- 67 antigen (blue reaction product) and $\beta_{1 \mathrm{C}}$ (brown reaction product) in two different breast carcinomas exhibiting low $(\mathbf{A})$ and high $(\mathbf{B})$ proliferative fractions. An inverse correlation is documented between the number of neoplastic cells immunoreactive for the Ki-67 antigen and the expression of $\beta_{1 \mathrm{C}}$. Original magnifications: $\mathbf{A}, \times 250 ; \mathbf{B}, \times 400$. 
of the neoplastic cells and on their infiltrative growth pattern, whereas the histological grading of breast carcinomas includes the evaluation of mitotic activity, in addition to tubule formation and nuclear atypia. ${ }^{11}$ The correlation of $\beta_{1 \mathrm{C}}$ expression with tumor grade in breast carcinomas, however, is not justified by the higher proliferative fraction of high-grade carcinomas, because in multivariate analysis both grade and Ki-67 labeling were independently associated with $\beta_{1 \mathrm{C}}$ immunoreactivity.

Our results strengthen the role of $\beta_{1 \mathrm{C}}$ in the negative regulation of cell cycle progression and cell proliferation, which has been put forward by in vitro experiments. ${ }^{3-6}$ Indeed, we have shown a strong inverse correlation between $\beta_{1 C}$ expression and the percentage of neoplastic cells immunoreactive for the Ki-67 antigen, a consolidated marker of cycling cells. Double immunocytochemical experiments showed in most cases a mutually exclusive immunoreactivity for either antigen at the single-cell level. These data are consistent with a pivotal role in vivo of $\beta_{1 \mathrm{C}}$ in the control of cell proliferation in invasive breast carcinomas.

A similar inverse correlation between $\beta_{1 \mathrm{C}}$ immunoreactivity and Ki-67 labeling has been reported for squamous cell carcinomas and adenocarcinomas of the lung. ${ }^{8}$ Furthermore, down-regulation of $\beta_{1 C}$ expression has been previously noted in regenerative areas of hyperplastic prostates displaying hyperchromatic nuclei and cellular crowding. ${ }^{5}$

A molecular mechanism by which $\beta_{1 C}$ may inhibit cell proliferation has been recently highlighted. ${ }^{6} \beta_{1 \mathrm{C}}$ is coexpressed with $\mathrm{p} 27^{\mathrm{kip} 1}$ in benign and neoplastic prostates, and both proteins are coordinately down-regulated in $54 \%$ of prostatic carcinomas. Furthermore, in vitro forced expression of $\beta_{1 C}$ is accompanied by increased levels of p2 $7^{\text {kip } 1}$, by selective inhibition of cyclin A-dependent kinase activity, and by increased p2 $7^{\mathrm{kip} 1}$ association with cyclin A. These data point to a role for $\beta_{1 \mathrm{C}}$ as an upstream regulator of p27 $7^{\mathrm{kip} 1}$, whose loss is an adverse prognostic factor in breast cancer. ${ }^{15,16}$

Although the short follow-up time (2-3 years) of the current series of patients does not allow for survival analyses, the correlation of $\beta_{1 \mathrm{c}}$ expression with tumor size, grade, and proliferative fraction and its alleged role as an upstream regulator of $\mathrm{p} 27^{\mathrm{kip} 1}$ make this integrin variant a likely novel prognostic parameter for invasive carcinomas of the breast.

\section{References}

1. Schwartz MA, Schaller MD, Ginsberg MH: Integrins: emerging paradigms of signal transduction. Annu Rev Cell Dev Biol 1995, 11:549599

2. Languino LR, Ruoslahti E: An alternative form of the integrin $\beta_{1}$ subunit with a variant cytoplasmic domain. J Biol Chem 1992, 267: 7116-7120

3. Fornaro M, Zheng DQ, Languino LR: The novel structural motif Gln795-GIn802 in the integrin $\beta_{1 \mathrm{C}}$ cytoplasmic domain regulates cell proliferation. J Biol Chem 1995, 270:24666-24669

4. Meredith J Jr, Takada Y, Fornaro M, Languino LR, Schwartz MA Inhibition of cell cycle progression by the alternatively spliced integrin $\beta_{1 \mathrm{c}}$. Science 1995, 269:1570-1572

5. Fornaro M, Manzotti M, Tallini G, Slear AE, Bosari S, Ruoslahti E, Languino LR: $\beta 1 \mathrm{C}$ integrin in epithelial cells correlates with a nonproliferative phenotype: forced expression of $\beta_{1 \mathrm{c}}$ inhibits prostate epithelial cell proliferation. Am J Pathol 1998, 153:1079-1087

6. Fornaro M, Tallini G, Zheng DQ, Flanagan M, Manzotti M, Languino LR: p27 (kip1) acts as a downstream effector of and is coexpressed with the $\beta_{1 \mathrm{C}}$ integrin in prostatic adenocarcinoma. J Clin Invest 1999, 103:321-329

7. Fornaro M, Tallini G, Bofetiado CJM, Bosari S, Languino LR: Downregulation of $\beta_{1 \mathrm{C}}$ integrin, an inhibitor of cell proliferation, in prostate carcinoma. Am J Pathol 1996, 149:765-773

8. Patriarca C, Alfano RM, Sonnenberg A, Graziani D, Cassani B, De Melker A, Colombo P, Languino LR, Fornaro M, Warren WH, Coggi G, Gould VE: Integrin laminin receptor profile of pulmonary squamous cell and adenocarcinoma. Hum Pathol 1998, 29:1208-1215

9. World Health Organization: Histological typing of breast tumours. International Histological Classification of Tumours, ed 2. Geneva, WHO, 1981, pp 15-25

10. Rosen PP, Oberman HA: Tumors of the Mammary Gland. Washington DC: Armed Forces Institute of Pathology, 1993

11. Elston CW, Ellis IO: Pathological prognostic factors in breast cancer: the value of histological grade in breast cancer. Histopathology 1991 , 19:403-410

12. Veronesi U, Paganelli G, Galimberti V, Viale G, Zurrida S, Bedoni M, Costa A, De Cicco C, Geraghty JG, Luini A, Sacchini V, Veronesi P: Sentinel-node biopsy to avoid axillary dissection in breast cancer with clinically negative lymph-nodes. Lancet 1997, 349:1864-1867

13. Doglioni C, Gambacorta M, Zamboni G, Coggi G, Viale G: Immunocytochemical localization of progesterone receptors in endocrine cells of the human pancreas. Am J Pathol 1990, 137:999-1005

14. Gleason DF: Classification of prostatic carcinomas. Cancer Chemother Rep 1966, 50:125-128

15. Tan P, Cady B, Wanner M, Worland P, Cukor B, Magi-Galluzzi C, Lavin P, Draetta G, Pagano M, Loda M: The cell cycle inhibitor p27 is an independent prognostic marker in small $(\mathrm{T} 1 \mathrm{a}, \mathrm{b})$ invasive breast carcinomas. Cancer Res 1997, 57:1259-1263

16. Gillett CE, Smith P, Peters G, Lu X, Barnes DM: Cyclin-dependent kinase inhibitor $\mathrm{p} 27^{\mathrm{kip} 1}$ expression and interaction with other cell cycle-associated proteins in mammary carcinoma. J Pathol 1999, 187:200-206 